\title{
PENGARUH GAYA KEPEMIMPINAN DAN KOMPENSASI TERHADAP KINERJA APARATUR DESA SUKAMAJU KECAMATAN BABAT SUPAT KABUPATEN MUSI BANYUASIN
}

\author{
Fery Supriyanto $^{1)}$ Hoirul Rohim ${ }^{2)}$ \\ STIE Rahmaniyah Sekayu
}

\begin{abstract}
Abstrak. Penelitian ini bertujuan untuk mengetahui dan menganalisis pengaruh Gaya Kepemimpinan dan Kompensasi Terhadap Kinerja Aparatur Desa Sukamaju Kecamatan Babat Supat Kabupaten Musi Banyuasin. Data penelitian diperoleh dari kuesioner, studi kepustakaan, dan beberapa observasi langsung sesuai tujuan penelitian. Metode analisisnya menggunakan Metode Kuantitatif dengan uji hipotesis, yaitu uji t. Jumlah sampel sebesar 70 Aparatur Desa Sukamaju Kecamatan Babat Supat Kabupaten Musi Banyuasin. Hasil penelitian menunjukkan Gaya Kepemimpinan dan Kompensasi berpengaruh signifikan terhadap Kinerja Aparatur. Dari penelitian ini diperoleh nilai perhitungan uji $t$ diperoleh $t$ hitung sebesar 25,099 > 1.667 maka Ha diterima dan Ho ditolak, berarti ada pengaruh signifikan antara X1 (gaya kepemimpinan) X2 (Kompensasi) dengan Y (kinerja)..
\end{abstract}

Kata Kunci :Gaya Kepemimpinan, Kompensasi, Kinerja.

\section{Pendahuluan}

Kepemimpinan yang efektif sangat dipengaruhi oleh kepribadian pemimpin. Setiap pemimpin perlu memiliki aspek - aspek kepribadian yang dapat menunjang usahanya dalam mewujudkan hubungan manusia yang efektif dengan anggota organisasinya. Kesuksesan atau kegagalan suatu organisasi ditentukan oleh banyak hal, yang salah satunya adalah kepemimpinan yang berjalan dalam organisasi tersebut. Pemimpin yang sukses adalah apabila pemimpin tersebut mampu menjadi pencipta dan pendorong bagi bawahannya dengan menciptakan suasana dan budaya kerja yang dapat memacu pertumbuhan dan perkembangan kinerja karyawannya. Pemimpin tersebut memiliki kemampuan untuk memberikan pengaruh positif bagi karyawannya untuk melakukan pekerjaan sesuai dengan yang diarahkan dalam rangka mencapai tujuan yang ditetapkan. Menurut Kartono (2012:34) gaya kepemimpinan adalah sifat, kebiasaan, tempramen, watak dan kepribadian yang membedakan seseorang pemimpin dalam berinteraksi dengan orang lain. Gaya kepemimpinan adalah cara seorang pemimpin mempengaruhi perilaku bawahan, agar mau bekerja sama dan bekerja secara produktif untuk mencapai tujuan organisasi.

Menurut Hasibuan (2017:119) Kompensasi adalah semua pendapatan yang berbentuk uang, barang langsung atau tidak langsung yang diterima karyawan sebagai immbalan atas jasa yang diberikan kepada perusahaan. Selain itu sistem kompensasi perusahaan memiliki dampak terhadap kinerja strategis.

Menurut Mangkunegara (2016:67) istilah kinerja berasal dari kata job performance atau Actual Permormance (prestasi kerja atau prestasi sesungguhnya yang dicapai seseorang). Pengertian kinerja adalah hasil kerja secara kualitas dan 
kuantitas yang dicapai oleh seorang pegawai dalam melaksanakan tugasnya sesuai dengan tanggung jawab yang diberikan kepadanya.

Desa Sukamaju Kecamatan Babat Supat yang terletak di Jalan PalembangJambi KM. 102, adalah Desa yang bisa dikatakan Desa yang aktif dengan banyaknya program yang sering dilaksanakan, baik di bidang pemerintahan, pemberdayaan, pembangunan ataupun pembinaan masyarakat. Agar mampu mencapai visi dan misi maka desa itu sendiri perlu meningkatkan kinerja aparaturnya nya. Kinerja aparatur yang baik dapat membantu menjalankan dan mengelolah jalannya pemerinthan dengan baik juga.

Meningkatkan kinerja aparatur dapat memudahkan Desa mencapai tujuan yang diharapkan, salah satu cara meningkatkan kinerja aparaturnya. Desa perlu memliliki seorang pimpinan yang mampu mengontrol, mengarahkan, dan membimbing para anggota aparaturnya yang ada di Desa. Gaya kepemimpinan yang diperankan pimpinan akan menentukan dan mempengaruhi kinerja aparatur Desa. Demikian pula dengan pemberian kompensasi, jika kompensasi yang diberikan perusahaan kepada para anggota karyawan sesuai dengan harapan, maka akan mendorong semangat dan memotivasi para anggota karyawan dalam bekerja.

Berdasarkan keadaan yang telah dijelaskan diatas peneliti tertarik untuk melakukan penelitian dengan judul: "Pengaruh Gaya Kepemimpinan dan Kompensasi Terhadap Kinerja Aparatur Desa Sukamaju Kecamatan Babat Supat".

\section{Tinjauan Pustaka}

\subsection{Pengertian Gaya Kepemimpinan}

Menurut Armstrong (2014;133), Kepemimpinan adalah proses memberi inspirasi kepada semua karyawan agar bekerja sebaik-baiknya untuk mencapai hasil yang diharapkan. Pengertian tersebut berarti bahwa Kepemimpinan adalah kegiatan untuk mempengaruhi orang lain, agar mereka mau bekerja sama untuk mencapai tujuan yang diinginkan.

Menurut Veitzhal Rivai (2012:53) kepemimpinan adalah kemampuan seseorang pemimpin untuk mempengaruhi orang lain dengan cara memancing tumbuhnya perasaan yang positif dalam diri orang-orang yang dipimpinnya untuk mencapai tujuan yang diinginkan. Sedangkan menurut Terry George R yang dialih bahasakan oleh Kartini Kartono (2011:57) kepemimimpinan adalah kegiatan mempengaruhi orang-orang agar mereka suka berusaha mencapai tujuan-tujuan kelompok.

Selain itu, menurut Miftah Thoha (2011:9) kepemimpinan adalah kegiatan untuk memengaruhi perilaku orang lain atau seni memengaruhi perilaku manusia baik perorangan maupun kelompok.

Berdasarkan definisi-definisi tersebut dapat disimpulkan bahwa kepemimpinan merupakan upaya untuk mempengaruhi kegiatan - kegiatan seseorang atau kelompok, agar orang bersedia bekerja secara efektif dan efisien dalam mencapai tujuan yang telah ditentukan pada situasi tertentu. Setiap pemimpin tentunya memiliki gaya kepemimpinan yang berbeda antara satu dengan yang lainnya. Dasar yang sering dipergunakan dalam mengelompokkan gaya kepemimpinan yang ada adalah tugas yang dirasakan harus dilakukan oleh pemimpin, kewajiban yang pemimpin harapkan diterima oleh bawahan dan lain sebagainya. 


\subsection{Fungsi Kepemimpinan}

Fungsi kepemimpinan berhubungan langsung dengan situasi sosial dalam kehidupan kelompok atau instansi masing-masing, yang mengisyaratkan bahwa setiap pemimpin berada di dalam dan bukan di luar situasi itu. Secara operasional ada lima fungsi pokok kepemimpinan yang di kemukakan oleh Veitzhal Rivai (2012:34), yaitu:

\section{Fungsi Instruksi}

Fungsi ini bersifat komunikasi satu arah. Pemimpin sebagai komunikator merupakan pihak yang menentukan apa, bagaimana, bilamana, dan dimana perintah itu dikerjakan agar keputusan dapat dilaksanakan secara efektif.

\section{Fungsi Konsultasi}

Fungsi ini bersifat komunikasi dua arah. Pada tahap pertama dalam usaha menetapkan keputusan, yang mengharuskan berkonsultasi dengan orang-orang yang dipimpinnya yang dinilai mempunyai berbagai bahan informasi yang memperoleh masukan berupa umpan balik (feedback) untuk memperbaiki dan menyempurnakan keputusan-keputusan yang telah ditetapkan.

3. Fungsi Partisipasi

Dalam menjalankan fungsi ini pemimpin berusaha mengaktifkan orangorang yang dipimpinnya, baik dalam ke ikut sertaan pengambilan keputusan maupun dalam melaksanakannya.

4. Fungsi Delegasi

Fungsi ini dilaksanakan dengan memberikan pelimpahan wewenang membuat atau menetapkan keputusan, baik melalui persetujuan maupun tanpa persetujuan dari pemimpin.

5. Fungsi Pengendalian

Fungsi pengendalian bermaksud bahwa kepemimpinan yang sukses atau efektif mampu mengatur aktivitas anggotanya secara terarah dan dalam koordinasi yang efektif sehingga memungkinkan tercapainya tujuan bersama secara maksimal.

Siagian (2012: 47), mengemukakan lima fungsi kepemimpinan yaitu:

1. Pimpinan sebagai penentu arah, yaitu sebagai penentu arah yang hendak ditempuh oleh organisasi menuju tujuannya sedemikian rupa sehingga mengoptimalkan pemanfaatan segala sarana dan prasarana yang tersedia.

2. Pimpinan sebagai wakil atau juru bicara, yaitu pimpinan merupakan puncak organisasi menjadi wakil dan juru bicara resmi organisasi dalam hubungan dengan berbagai pihak di luar organisasi dalam hubungan dengan berbagai pihak diluar organisasi.

3. Pimpinan sebagai komunikator yang efektif, yaitu suatu proses pemeliharaan hubungan yang baik ke dalam maupun keluar oleh seorang pimpinan melalui komunikasi baik lisan maupun tertulis.

4. Pimpinan sebagai mediator yang handal, yaitu seorang pimpinan yang berfungsi sebagai mediator dalam menyelesaikan situasi konflik yang mungkin timbul dalam suatu organisasi, tanpa mengurangi pentingnya situasi konflik dalam mengurangi pentingnya situasi konflik dalam hubungan keluar yang dihadapi dan diatasi.

5. Pimpinan sebagai integrator yang aktif, yaitu kepemimpinan berfungsi sebagai penyatu dari berbagai individu dan kelompok yang berbeda pola pikir dan cara bertindak yang berkotak-kotak menuju pada tujuan bersama. 


\subsection{Dimensi dan Indikator Gaya Kepemimpinan}

Menurut Veitzhal Rivai (2012:53) seorang pemimpin dalam mengimplementasikan kepemimpinannya harus mampu secara dewasa melaksanakan kedewasaan terhadap instansi atau organisasinya, kepemimpinan dibagi kedalam lima dimensi dan dua belas indikator, yaitu :

1. Kemampuan untuk membina kerjasama dan hubungan yang baik

a. Membina kerjasama dan hubungan baik dengan bawahan dalam pelaksanaan tugas yang menjadi tanggung jawab masing-masing

b. Kemampuan seorang pemimpin dalam memotivasi bawahannya

2. Kemampuan yang efektivitas
a. Mampu menyelesaikan tugas diluar kemampuan
b. Menyelesaikan tugas tepat waktu
c. Hadir tepat waktu dan tidak terlambat

3. Kepemimpinan yang partisipatif

a. Pengambilan keputusan secara musyawarah

b. Dapat menyelesaikan masalah secara tepat

c. Mampu dalam meneliti masalah yang terjadi pada pekerjaan

4. Kemampuan dalam mendelegasikan tugas atau waktu

a. Bersedia untuk membawa kepentingan pribadi dan organisasi kepada kepentingan yang lebih luas, yaitu kepentingan organisasi menggunakan waktu sisa untuk keperluan pribadi

b. Mampu dalam menyelesaikan tugas sesuai dengan target

5. Kemampuan dalam mendelegasikan tugas atau wewenang

a. Tanggung jawab seorang pemimpin dalam menyelesaikan tugas mana yang harus ditangani sendiri dan mana yang harus ditangani secara kelompok.

b. Memberikan bimbingan dan pelatihan dalam pengambilan keputusan

\subsection{Pengertian Kompensasi}

Menurut Hasibuan (2017:119) Kompensasi adalah semua pendapatan yang berbentuk uang, barang langsung atau tidak langsung yang diterima karyawan sebagai imbalan atas jasa yang diberikan kepada perusahaan. Pembentukan sistem kompensasi yang efektif merupakan bagian penting dari manajemen sumber daya manusia karena membantu menarik dan mempertahankan pekerjaan-pekerjaan yang berbakat. Selain itu sistem kompensasi perusahaan memiliki dampak terhadap kinerja strategis.

Menurut Handoko (2014:155) Kompensasi adalah segala sesuatu yang diterima para karyawan sebagai balas jasa untuk kerja mereka. Program-program kompensasi juga penting bagi perusahaan, karena mencermintakan upaya organisasi untukmempertahankan sumber daya manusia.

Menururt Wibowo (2016:271) Kompensasi adalah jumlah paket yang ditawarkan organisasi kepada pekerja sebagai imbalan atas penggunaan tenaga kerjanya. Menurut Yani tahun 2012. Kompensasi adalah bentuk pembayaran dalam bentuk manfaat dan insentif untuk memotivasi karyawan agar produktivitas kerja semakin meningkat.

\subsection{Tujuan Kompensasi}

Tujuan kompensasi menurut badriyah (2015:155) adalah sebagai berikut:

1. Ikatan kerja sama 
Dengan pemberian kompensasi terjalinlah ikatan kerjasama formal antara majikan dengan karyawan. Karyawan harus mengerjakan tugasnya dengan baik, sedangkan pengusaha/majikan harus membayar kompensasi.

2. Kepuasan kerja

Karyawan dapat memenuhi kebutuhan-kebutuhannya dengan pemberian kompensasi.

3. Pengadaan efektif

Jika program kompensasi ditetapkan cukup besar, pengadaan karyawan yang qualified untukperusahaan lebih mudah.

4. Motivasi

jika balas jasa yang diberikan cukup besar, manajer akan lebih mudah memotivasi bahawannya.

5. Stabilitas karyawan

Dengan program kompensasi atas prinsip adil dan layak serta eksternal konsistensinya yang kompetitif maka stabilitasnya karyawan lebih terjamin karena turnover yang relatif kecil.

6. Disiplin

Dengan pemberian balas jasa yang cukup besar maka disiplin karyawan semakin baik.

7. Pengaruh serikat buruh

Dengan program kompensasi yang baik pengaruh Serikat Buruh dapat dihindarkan dan karyawan akan konsenterasi pada pekerjaannya.

8. Pengaruh buruh

Jika program kompensasi sesuai dengan undang-undang perburuhan yang berlaku (seperti batas upah minimum), maka intervensi pemerintah dapat dihindari.

Sedangkan menurut Handoko tahun 2001 (dalam Widodo (2015:157)), tujuan kompensasi dapat diuraikan sebagai berikut:

1. Memperoleh personalia yang qualified.

2. Mempertahankan karyawan yang ada sekarang.

3. Menjamin keadilan.

4. Menghargai perilaku yang diinginkan.

5. Mengendalikan biaya - biaya.

6. Memenuhi peraturan-peraturan legal.

\subsection{Asas dan Metode Pemberian Kompensasi}

Menurut Badriyah (2015:158) menggambarkan bahwa asas kompensasi, yaitu:

a. Mereka merasakan adanya keadilan dalam penggajian.

b. Penghargaan yang dikaitkan dengan kinerja mereka.

c. Berkaitan dengan kebutuhan individu.

Dalam metode kompensasi (balas jasa) dikenal metode tunggal dan metode jamak.

a. Metode tunggal adalah metode yang dalam penetapan gaji pokoknya didasarkan atas ijazah terakhir dari pendidikan formal yang dimiliki pegawai.

b. Metode jamak adalah suatu metode yang dalam gaji pokok didasarkan atas beberapa pertimbangan, seperti ijazah, sifat pekerjaan, pendidikan formal, bahkan hubungan keluarga. 
Menurut Hasibuan (2017:122), asas kompensasi harus berdasarkan asas adil dan asas layak serta mempertahankan undang-undang perburuhan yang berlaku.

a. Asas adil besarnya kompensasi harus sesuai dengan prestasi kerja, jenis pekerjaan, tanggung jawab dan jabatan.

b. Asas layak dan wajar suatu kompensasi harus disesuaikan dengan kelayakannya. Meskipun tolak ukur layak sangat relatif, perusahaan dapat mengacu pada batas kewajaran yang sesuai dengan ketentuan yang diterapkan oleh pemerintah dan aturan lain secara konsisten.

Jadi kesimpulan yang dapat penulis sampaikan bahwa prinsip adil dan layak dalam pemberian kompensasi harus mendapatkan perhatian dari setiap perusahaan supaya menciptakan suasana kerja yang kondusif kepada karyawan, apapun metode yang digunakan hendaklah dapat memberikan kepuasan dan keadilan bagi semua pihak untuk mencapai tujuan bersama.

\subsection{Faktor Yang Mempengaruhi Kompensasi}

Menurut Badriyah (2015:16) faktor-faktor yang mempengaruhi kompensasi yang diberikan dapat diuraikan sebagai berikut:

1. Penawaran dan permintaan tenaga kerja

Jika pencari kerja (penawaran) lebih banyak daripada lowongan pekerjaan (permintaan), kompensasi relatif kecil. Sebaliknya, jika pencari kerja lebih sedikit daripada lowongan pekerjaan, kompensasi relatif semakin besar.

2. Kemampuan dan kesediaan perusahaan

Apabila kemampuan dan kesediaan perusahaan untuk membayar semakin baik, tingkat kompensasi semakin besar. Sebaliknya, jika kemampuan dan kesediaan perusahaan untuk membayar kurang maka tingkat kompensasi relatif kecil.

3. Serikat buruh/Organisasi karyawan

Apabila serikat buruhnya kuat dan berpengaruh, tingkat kompensasi semakin besar. Sebaliknya, jika serikat buruh tidak kuat dan kurang berpengaruh, tingkat kompensasi relatif kecil.

4. Produktivitas Kerja Pegawai

Jika produktivitas kerja pegawai baik dan banyak kompensasi akan semakin besar. Begitu juga sebaliknya, jika produktivitas

kerjanya buruk serta sedikit, maka kompensasinya semakin kecil.

5. Undang-undang dan Keppres

Menetapkan besarnya batas upah/balas jasa minimum. Peraturan pemerintah ini sangat penting agar pengusaha tidak sewenang-wenang menetapkan besarnya balas jasa bagi pegawai. Pemerintah berkewajiban melindungi masyarakat dari tindakan sewenang-wenang.

6. Biaya hidup/Cost of living

Apabila biaya hidup di suatu daerah tinggi, tingkat kompensasi/upahnya pun semakin besar. Sebaliknya, jika tingkat biaya hidup di suatu daerah rendah, tingkat kompensasi/upahnya pun relatif kecil.

7. Posisi jabatan pegawai

Pegawai yang menduduki jabatan lebih tinggi akan menerima gaji/kompensasi lebih besar. Sebaliknya, pegawai yang menduduki jabatan yang lebih rendah akan memperoleh gaji/kompensasi yang kecil.

8. Pendidikan dan pengalaman kerja 
Jika pendidikan lebih tinggi dan pengalaman kerja lebih lama, gaji/balas jasa akan semakin besar. Sebaliknya, pegawai yang berpendidikan rendah dan pengalam kerja yang kurang, tingkat gaji/kompensasinya kecil.

9. Kondisi perekonomian nasional

Apabila kondisi perekonomian nasional sedang maju, tingkat upah/kompensasi semakin besar karena mendekati kondisi full employment. Sebaliknya, jika kondisi perekonomian kurang maju (depresi) tingkat upah rendah karena terdapat banyak pengangguran (disqueshed unemployment).

10. Jenis dan sifat pekerjaan

Apabila jenis dan sifat pekerjaan yang sulit dan mempunyai risiko (finansial, keselamatan) yang besar, tingkat upah/balas jasanya semakin besar karena membutuhkan kecakapan serta ketelitian untuk mengerjakannya. Akan tetapi, jika jenis dan sifat pekerjaannya mudah dan resiko (finansial, kecelakaan) kecil, tingkat upah/balas jasanya relatif rendah.

\subsection{Dimensi dan Indikator Kompensasi}

Menurut Badriyah (2015:164) dimensi dan indikator kompensasi dibagi menjadi:

1. Gaji/upah

Adalah balas jasa yang dibayar secara periodik kepada pegawai yang tetap serta mempunyai jaminan yang pasti. Terdapat beberapa indikator dalam pemberian gaji, yaitu sebagai berikut:
a. Keadilan dalam pemberian gaji,
b. Kelayakan dalam pemberian gaji, dan
c. Ketepatan waktu dalam pemberian gaji.

2. Insentif

Adalah balas jasa yang diberikan kepada pegawai tertentu, yang prestasinya di atas prestasi standar, pemberian insentif dimaksudkan untuk memotivasi pegawai agar bekerja lebih bersemangat sehingga produktivitas pegawai meningkat. Terdapat beberapa indikator dalam pemberian insentif, yaitu sebagai berikut:
a. Keadilan dalam pemberian insentif,
b. Kelayakan dalam pemberian insentif, dan
c. Ketepatan waktu dalam pemberian insentif.

3. Bonus

Adalah balas jasa atas hasil pekerjaan yang telah dilaksanakan apabila melebihi target, diberikan satu sekali terima tanpa suatu ikatan pada masa yang akan datang, beberapa persen dari laba yang kemudian dibagikan kepada yang berhak menerima bonus. Terdapat beberapa indikator dalam pemberian bonus, yaitu sebagai berikut:

a. Keadilan dalam pemberian bonus,

b. Kelayakan dalam pemberian bonus, dan

c. Ketepatan waktu dalam pemberian bonus.

4. Tunjangan

Adalah pemberian kompensasi guna menciptakan rasa nyaman dan aman dalam bekerja, seperti tunjangan kesehatan, tunjangan hari tua, bayaran di luar jam kerja (sakit, cuti, libur besar), dll. Terdapat beberapa indikator dalam pemberian tunjangan, yaitu sebagai berikut:

a. Pemberian tunjangan kesehatan, 
b. Pemberian tunjangan hari raya, dan

c. Pemberian tunjangan kecelakaan.

5. Fasilitas

6. program pelayanan pegawai yang berupa fasilitas guna mempermudah pegawai dalam bekerja. Indikator dalam fasilitas, yaitu sebagai berikut:

a. Kelengkapan fasilitas kerja, dan

b. Kelayakan fasilitas kerja

\subsection{Pengertian Kinerja}

Menurut Wirawan (2015:892) menyatakan bahwa "kinerja adalah keluaran yang dihasilkan oleh fungsi-fungsi atau indikator- indikator suatu pekerjaan atau suatu profesi dalam waktu tertentu". Menurut Mangkunegara (2015:892) menyatakan bahwa "Kinerja adalah hasil kerja secara kualitas dan kuantitas yang dicapai oleh seorang pegawai dalam melaksanakan tugasnya sesuai tanggung jawab yang diberikan kepadanya".

Menurut Colquit (2016: 187) menyatakan bahwa "kinerja adalah nilai serangkaian perilaku pekerja yang memberikan kontribusi baik secara positif maupun negatif pada penyelesaian tujuan organisasi”. Menurut Gibson (2016: 188) menyatakan bahwa" pekerjaan yang berkaitan dengan tujuan organisasi seperti kualitas, efisiensi dan kriteria lain dari efektifitas. Kinerja merupakan terjemahan dari performance yang berarti hasil kerja seorang pekerja, sebuah proses manajemen atau suatu organisasi secara keseluruhan, dimana hasil kerja tersebut harus dapat ditunjukkan buktinya secara konkrit dan dapat diukur (Sedarmayanti (2013:260).

Berdasarkaan pengertian di atas, penulis menarik kesimpulan bahwa kinerja merupakan kualitas dan kuantitas dari suatu hasil kerja (output) individu maupun kelompok dalam suatu aktivitas tertentu yang diakibatkan oleh kemampuan alami atau kemampuan yang diperoleh dari proses belajar serta keinginan untuk berprestasi.

\subsection{Karakteristik Pegawai Yang Memiliki Kinerja Tinggi}

Sebuah studi tentang kinerja menemukan beberapa karakteristik pegawai yang memiliki kinerja yang tinggi. Mink (2013:76) menyebutkan beberapa karakteristik pegawai yang memiliki kinerja yang tinggi, meliputi :

a. Berorientasi pada prestasi

Pegawai yang memiliki kinerja yang tinggi, keinginan yang kuat membangun sebuah mimpi tentang apa yang mereka inginkan untuk dirinya.

b. Percaya diri

Pegawai yang kinerja tinggi memiliki sikap mental positif yang mengarahkannya bertindak dengan tingkat percaya diri yang tinggi.

c. Pengendalian Diri

Pegawai yang memiliki kinerja yang tinggi mempunyai rasa percaya diri yang sangat mendalam sehingga dapat mengendalikan dirinya dengan baik.

d. Kompetensi

Pegawai yang kinerjanya tinggi telah mengembangkan kemampuan yang spesifik dan kompeten yang digunakan dalam mencapai prestasi.

\subsection{Faktor yang Mempengaruhi Kinerja Pegawai}

Menurut Hasibuan (2012: 94) mengungkapkan bahwa "Kinerja merupakan gabungan tiga faktor penting, yaitu kemampuan dan minat seorang pekerja, kemampuan dan penerimaan atas penjelasan delegasi tugas dan peran serta tingkat 
motivasi pekerja”. Sedangkan menurut Menurut Nitisemito (2015: 109), terdapat berbagai faktor kinerja pegawai, antara lain:

a) Jumlah dan komposisi dari kompensasi yang diberikan

b) Penempatan kerja yang tepat

c) Pelatihan dan promosi

d) Rasa aman di masa depan (dengan adanya pesangon dan sebagainya)

e) Hubungan dengan rekan kerja

f) Hubungan dengan pemimpin

\subsection{Indikator Kinerja}

Sehubungan dengan ukuran penilaian prestasi kerja maka kinerja pegawai, menurut Sedarmayanti (2013: 260), diukur dengan indikator-indikator sebagai berikut:

a. Kuantitas hasil kerja, yaitu meliputi jumlah produksi kegiatan yang dihasilkan.

b. Kualitas hasil kerja, yaitu yang meliputi kesesuaian produksi kegiatan dengan acuan ketentuan yang berlaku sebagai standar proses pelaksanaan kegiatan maupun rencana organisasi.

c. Ketepatan waktu penyelesaian pekerjaan, yaitu pemenuhan kesesuaian waktu yang dibutuhkan atau diharapkan dalam pelaksanaan kegiatan.

Sedangkan menurut Suryadi Prawirosentono (2011:27), kinerja dapat dinilai atau diukur dengan beberapa indikator yaitu:

a) Efektifitas yaitu bila tujuan kelompok dapat dicapai dengan kebutuhan yang direncanakan.

b) Tanggung jawab merupakan bagian yang tak terpisahkan atau sebagai akibat kepemilikan wewenang

c) Disiplin yaitu taat pada hukum dan aturan yang belaku. Disiplin pegawai adalah ketaatan pegawai yang bersangkutan dalam menghormati perjanjian kerja dengan perusahaan dimana dia bekerja.

d) Inisiatif berkaitan dengan daya pikir, kreatifitas dalam bentuk suatu ide yang berkaitan tujuan perusahaan. Sifat inisiatif sebaiknya mendapat perhatian atau tanggapan perusahaan dan atasan yang baik. Dengan perkataan lain inisiatif pegawai merupakan daya dorong kemajuan yang akhirnya akan mempengaruhi kinerja pegawai.

\subsection{Hubungan Antara Gaya Kepemimpinan dan Kompensasi Terhadap Kinerja}

Menurut Tampubolon (2007:42), gaya kepemimpinan adalah perilaku dan strategi sebagai hasil kombinasi dari falsafah, keterampilan, sifat, sikap, yang sering diterapkan seorang pemimpin ketika ia mencoba mempengaruhi kinerja bawahanya.

Dalam teori jalur tujuan (Path Goal Theory) yang dikembangkan oleh House (1971:321) dalam Kreitner dan Kinicki (2005:313) menyatakan bahwa pemimpin mendorong kinerja yang lebih tinggi dengan cara memberikan kegiatan-kegiatan yang mempengaruhi bawahannya agar percaya bahwa hasil yang berharga bisa dicapai dengan usaha yang serius.

Selain itu menurut penelitian yang dilakukan oleh Harianto (2008), Reza (2010), Ainanur (2012), Nurcahyani (2012), dan Widyawan (2013), bahwa terdapat hubungan atau pengaruh gaya kepemimpinan terhadap kinerja karyawan dan dalam ini penelitian dilakukan di proyek konstruksi. Kesimpulan yang 
dihasilkan adalah jika seorang pemimpin di lapangan atau seorang mandor memiliki dan mampu memilih gaya kepemimpinan yang tepat dalam mengelola bawahannya, maka kinerja bawahan dapat terkontrol dengan baik dan mampu meningkatkan kinerjanya.

Sedangkan hubungan kompensasi terhadap kinerja. Kompensasi dapat dikatakan sebagai balas jasa yang diberikan untuk karyawan dalam suatu perusahaan. Besarnya kompensasi yang diberikan perusahaan pun tergantung pada kinerja karyawan tersebut. Semakin meningkat kinerja karyawan, semakin besar pula kompensasi yang diberikan oleh perusahaan baik kompensasi finansial maupun kompensasi nonfinansial. Dan begitupun sebaliknya, semakin rendah kinerja karyawan tersebut, maka semakin rendah kompensasi yang diberikan. Jadi, kompensasi yang diberikan untuk karyawan pun berbeda, contohnya ialah kompensasi untuk karyawan kontrak dan karyawan tetap. Sehingga kinerja mereka pun berbeda karena karyawan kontrak sedikit merasa terbebani karena adanya batasan waktu kerja mereka. Berbeda halnya dengan karyawan tetap yang terus berusaha untuk meningkatkan kinerjanya demi mencapai peningkatan karier.

\subsection{Kerangka Pemikiran}

Untuk menjelaskan variabel-variabel dalam penelitian ini berdasarkan konsep pemecahan masalah yang telah diidentifikasi dan dirumuskan akan dijelaskan melalui kerangka pemikiran berikut ini :

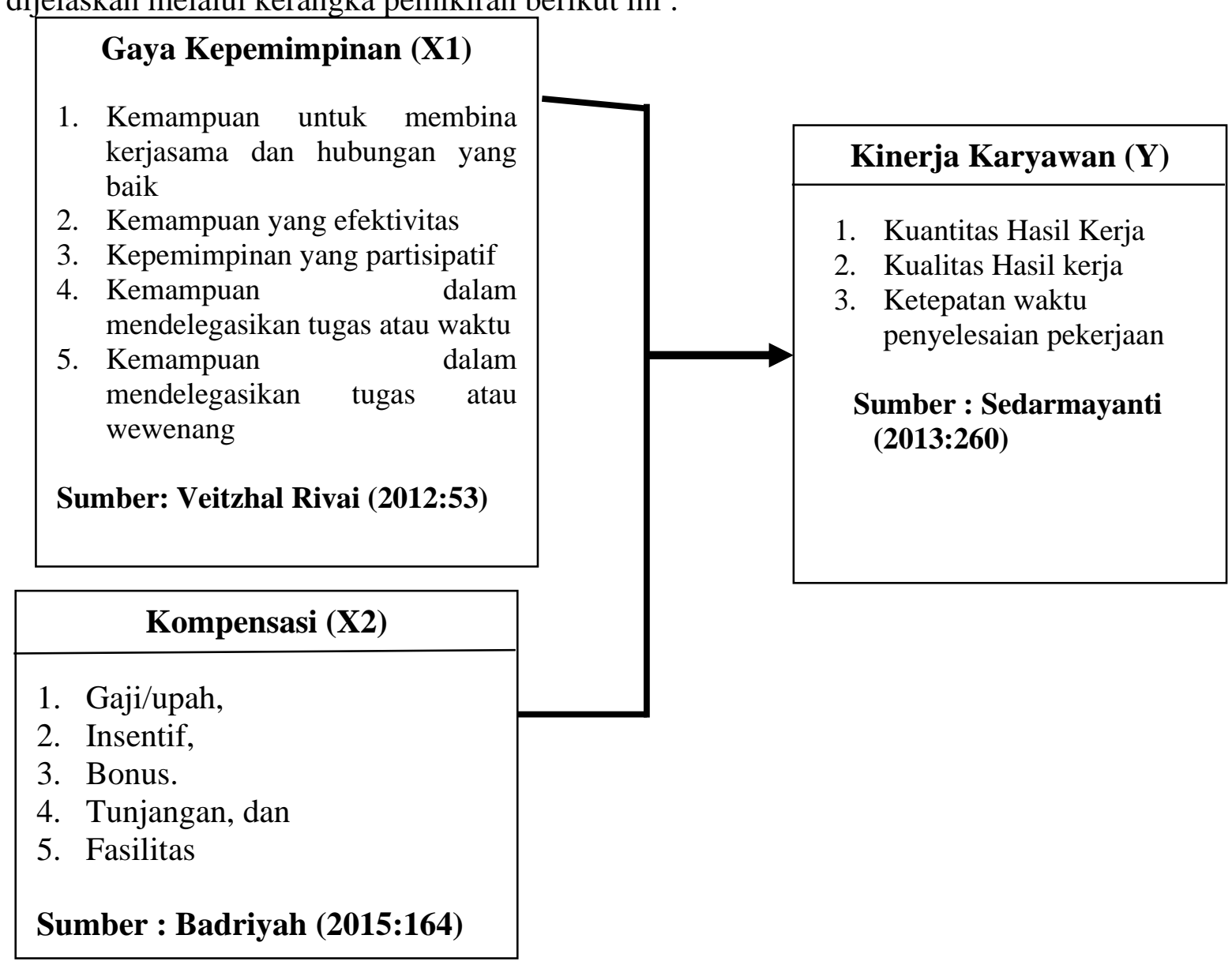

KerangkaPemikiran 


\subsection{Hipotesis}

Menurut Sugiyono (2013: 22) Hipotesis merupakan jawaban sementara terhadap rumusan masalah penelitian, dimana rumusan masalah penelitian telah dinyatakan dalam bentuk pertanyaan. Hipotesis dikatakan sementara karena jawaban yang diberikan baru didasarkan pada teori. Berdasarkan rumusan masalah dan teori yang telah dikemukan di atas maka penulis menemukan suatu hipotesis sebagai berikut:

Ho = kepemimpinan dan kompensasi tidak berpengaruh positif dan signifikan terhadap kinerja aparatur Desa Sukamaju Kecamatan Babat Supat Kabupaten Musi Banyuasin.

$\mathrm{Ha}=$ kepemimpinan dan kompensasi berpengaruh positif dan signifikan terhadap kinerja aparatur Desa Sukamaju Kecamatan Babat Supat Kabupaten Musi Banyuasin.

\section{Metode Penelitian}

\subsection{Data}

Metode penelitian yang digunakan dalam penelitan ini adalah metode kuantitatif. Sugiyono (2013: 14), menjelaskan bahwa metode kuantitatif adalah peneltian dengan metode angka atau data kualitatif yang diangkakan. Jenis data yang digunakan dalam penelitian ini adalah:

1. Data Primer

Data primer dari penelitian ini adalah kuesioner yang disebarkan kepada aparatur desa pada Kantor Desa Sukamaju Kecamatan Babat Supat Kabupaten Musi Banyuasin.

2. Data Sekunder

Data sekunder dari penelitian ini berupa bukti, catatan atau laporan historis yang telah tersusun dalam arsip (data dokumenter) yang ada pada Kantor Desa Sukamaju Kecamatan Babat Supat Kabupaten Musi Banyuasin.

\subsection{Operasionalisasi Variabel}

Operasionalisasi variabel dibuat untuk memudahkan pengumpulan data dan menghindari perbedaan interpensi serta membatasi ruang lingkup variabel. Variabel yang dimasukkan dalam operasional adalah variabel penting yang dapat diukur dan dipertanggungjawabkan dengan sumber yang jelas. Definisi operasional penelitian ini dapat dilihat pada tabel berikut ini: 
Tabel 1.1 Operasionalisasi variabel

\begin{tabular}{|c|c|c|c|c|}
\hline $\begin{array}{c}\text { Varia } \\
\text { bel }\end{array}$ & Definisi Variabel & Indikator Variabel & $\begin{array}{l}\text { Nomo } \\
\mathbf{r} \\
\text { Item } \\
\text { Perta } \\
\text { nyaan }\end{array}$ & $\begin{array}{c}\text { Skala } \\
\text { Peng } \\
\text { ukura } \\
\text { n }\end{array}$ \\
\hline $\begin{array}{c}\text { Gaya } \\
\text { kepemi } \\
\text { mpina } \\
\mathrm{n}(\mathrm{X})\end{array}$ & $\begin{array}{l}\text { Gaya kepemimpinan } \\
\text { adalah kemampuan } \\
\text { seseorang pemimpin } \\
\text { untuk mempengaruhi } \\
\text { orang lain dengan } \\
\text { cara memancing } \\
\text { tumbuhnya perasaan } \\
\text { yang positif dalam } \\
\text { diri orang-orang yang } \\
\text { dipimpinnya untuk } \\
\text { mencapai tujuan yang } \\
\text { diinginkan. } \\
\text { Veitzhal } \\
(2012: 53)\end{array}$ & $\begin{array}{l}\text { 1. Kemampuan untuk membina } \\
\text { kerjasama dan hubungan yang } \\
\text { baik } \\
\text { 2. Kemampuan yang efektivitas } \\
\text { 3. Kepemimpinan yang partisipatif } \\
\text { 4. Kemampuan dalam } \\
\text { mendelegasikan tugas atau waktu } \\
\text { 5. Kemampuan dalam } \\
\text { mendelegasikan tugas atau } \\
\text { wewenang }\end{array}$ & $\begin{array}{c}1-2 \\
3-5 \\
6-8 \\
9-10 \\
11-12\end{array}$ & $\begin{array}{l}\text { Skala } \\
\text { Likert }\end{array}$ \\
\hline $\begin{array}{l}\text { Kompe } \\
\text { nsasi } \\
\text { (X) }\end{array}$ & $\begin{array}{l}\text { kompensasi } \\
\text { merupakan pemberian } \\
\text { balas jasa langsung } \\
\text { dan tidak langsung, } \\
\text { berupa uang atau } \\
\text { barang kepada } \\
\text { pegawai sebagai balas } \\
\text { jasa yang diberikan } \\
\text { kepada } \\
\text { perusahaan".Badriyah } \\
\text { (2015:164) }\end{array}$ & $\begin{array}{l}\text { 1. Gaji/upah } \\
\text { 2. Insentif } \\
\text { 3. Bonus. } \\
\text { 4. Tunjangan, dan } \\
\text { 5. Fasilitas }\end{array}$ & $\begin{array}{c}1-3 \\
4-6 \\
7-9 \\
10-12 \\
13-14\end{array}$ & $\begin{array}{l}\text { Skala } \\
\text { Likert }\end{array}$ \\
\hline $\begin{array}{l}\text { Kinerj } \\
\mathrm{a}(\mathrm{Y})\end{array}$ & $\begin{array}{l}\text { Kinerja merupakan } \\
\text { Hasil kerja seorang } \\
\text { pekerja, sebuah } \\
\text { proses manajemen } \\
\text { atau suatu organisasi } \\
\text { secara Keseluruhan, } \\
\text { Dimana hasil kerja } \\
\text { tersebut harus dapat } \\
\text { ditunjukkan buktinya } \\
\text { secara konkrit dan } \\
\text { dapat diukur } \\
\text { (Sedarmayanti } \\
(2013: 260)\end{array}$ & $\begin{array}{l}\text { 1. Kuantitas kerja } \\
\text { 2. Kualitas kerja } \\
\text { 3. Ketepatan waktu }\end{array}$ & $\begin{array}{l}1 \\
2 \\
3\end{array}$ & $\begin{array}{l}\text { Skala } \\
\text { Likert }\end{array}$ \\
\hline
\end{tabular}




\subsection{Populasi, Sampel dan Teknik Pengambilan Sampel}

Menurut Arikunto (2012:205) populasi diartikan sebagai keseluruhan dari subjek atau objek penelitian. Jika seorang peneliti ingin meneliti semua elemen yang ada didalam wilayah penelitiannya, maka penelitiannya itu merupakan penelitian populasi. Populasi dalam penelitian ini adalah seluruh Aparatur Desa Sukamaju Kecamatan Babat Supat Kabupaten Musi Banyuasin yang berjumlah 70 orang.

Sampel adalah bagian dari jumlah dan karakteristik yang dimiliki oleh populasi tersebut (Sugiyono, 2011:81). Dengan demikian sampel adalah sebagian dari populasi yang karakteristiknya hendak diselidiki, dan bisa mewakili keseluruhan populasinya sehingga jumlahnya lebih sedikit dari populasi. Menurut Arikunto (2013: 134-185) sampel adalah sebagian atau wakil populasi yang diteliti. Dalam penelitian ini Sampel diambil dengan menggunakan teknik sampling jenuh. Sampel dalam penelitian ini adalah seluruh populasi dari penelitian ini yaitu seluruh seluruh aparatur Desa Sukamaju Kec. Babat Supat Kab. Musi Banyuasin yang berjumlah 70 orang.

Dalam penelitian ini Sampel diambil dengan menggunakan cara sampling jenuh. Sampling Jenuh adalah teknik penentuan sampel bila semua anggota populasi digunakan sebagai sampel (Sugiyono, 2012:68).

\subsection{Teknik Analisis Data}

Analisis data yang digunakan dalam penelitian ini adalah menggunakan bantuan SPSS versi 24. Analisis data yang dilakukan dalam penelitian ini adalah sebagai berikut:

\section{Uji Validitas}

Uji validitas item atau butir kuesioner dapat dilakukan dengan menggunakan program SPSS versi 24. Untuk proses ini, akan digunakan Uji Correlation Product Moment. Dalam uji ini, setiap item akan diuji relasinya dengan skor total variabel yang dimaksud. Dengan kriteria:

a. jika $\mathrm{r}$ hitung $>\mathrm{r}$ tabel dengan tingkat signifikansi sebesar 5\% maka item kuesioner penelitian dapat dikatakan valid atau layak dijadikan item pertanyaan dalam penelitan.

b. jika $\mathrm{r}$ hitung $<\mathrm{r}$ tabel dengan tingkat signifikansi sebesar 5\% maka item kuesioner penelitian dapat dikatakan tidak valid atau tidak layak dijadikan item pertanyaan dalam penelitan.

\section{Uji Reliabilitas}

Untuk menguji reliabilitas instrumen dalam penelitian ini yaitu menggunakan uji Cronbach's Alfa dimana teknik Cronbach's Alfa dilakukan untuk jenis data essay. Dalam Sugiyono (2013: 282), yaitu:

Rumus:

$$
\begin{array}{|l|l|}
\hline & \boldsymbol{r}_{\mathbf{1}} \frac{\boldsymbol{k}}{(\boldsymbol{k}-\mathbf{1})}\left\{\mathbf{1}-\frac{\sum \boldsymbol{s}_{\mathbf{1}}^{2}}{\boldsymbol{s}_{\mathbf{1}}}\right\} \\
r_{1} & \begin{array}{l}
\text { keterangan: } \\
k
\end{array} \\
S_{1}^{2} & =\text { koefisiensi reliabilitas } \\
& =\text { devianyaknya butir pertanyaan }
\end{array}
$$


$\sum S_{1}^{2}=$ jumlah deviasi standar butir

3. Asumsi Klasik

1. Uji Normalitas bertujuan untuk mengetahui apakah varibel-variabel penelitian memiliki distribusi normal atau tidak. Uji normalitas dalam penelitian ini dilaksanakan dengan menggunakan analisis grafik. Analisis grafik yang andal untuk menguji normalitas data adalah dengan melihat histogram dan normal probability plot. Histogram merupakan grafik yang membandingkan data observasi dengan distribusi yang mendekati normal. Sedangkan normal probability plot membandingkan distribusi kumulatif dari distribusi normal. Kriteria pengambilan keputusan dalam pengujian normalitas menggunakan probability plot.

2. Uji Multikolinieritas bertujuan untuk mengetahui apakah ada korelasi di antara variabel bebas (independen). Kriteria pengambilan keputusan penggunaan nilai toleran dan VIF tersebut menurut Ghozali (2016: 104) adalah jika nilai toleran $>0,10$ atau nilai VIF $<10$ maka tidak ada multikoleniaritas di antara variabel independen. Sebaliknya, jika nilai toleran $\leq 0,10$ atau nilai VIF $\geq 10$ maka ada multikoleniaritas di antara variabel independen.

3. Uji Heteroskedastisitas, bertujuan mengetahui apakah dalam model regresi terjadi ketidaksamaan varian dari residual satu pengamatan ke pengamatan yang lain. Kriteria pengambilan keputusan dalam pengujian ini menurut Ghozali (2016: 134) adalah jika ada pola tertentu, seperti titik-titik yang ada membentuk pola tertentu yang teratur (bergelombang, melebar kemudian menyempit) maka telah terjadi heteroskesdatisitas. Sebaliknya, jika tidak ada pola yang jelas serta titik-titik menyebar di atas dan di bawah angka 0 pada sumbu Y maka tidak terjadi heteroskesdatisitas.

\section{Analisis Regresi Linear Berganda}

Untuk mengetahui pengaruh antara gaya kepemimpinan dan kompensasi terhadap kinerja digunakan teknik analisis regresi linier berganda. Analisis linier berganda digunakan untuk meramalkan bagaimana keadaan (naik turunnya) variabel dependen, bila dua atau lebih variabel independen sebagai faktor prediktor dimanipulasi (dinaik turunkan nilainya). Analisis ini menggunakan rumus persamaan berikut (Sugiyono, $2012: 277$ ) :

$$
Y^{\prime}=a+b^{1} X^{1}+b^{2} X^{2}+e
$$

Dimana:

$\mathrm{Y}^{\prime}=$ Subyek dalam variabel dependen yang diprediksikan dalam hal Kinerja

$\mathrm{a}=\mathrm{Y}$ bila $\mathrm{X}=0$ (harga konstan)

$\mathrm{b}=$ Angka arah atau koefisien regresi, yang menunjukkan angka peningkatan ataupun penurunan variabel independen. Bila b (+) maka naik, dan bila (-) maka terjadi penurunan.

$\mathrm{X} 1=$ Variabel independen, yaitu gaya kepemimpinan

$\mathrm{X} 2=$ Variabel Independen, yaitu kompensasi

\section{Analisis Korelasi}

Menurut Sugiyono (2013: 14), pedoman untuk memberikan interprestasi koefisien korelasi sebagai berikut :

a. $0,00-0,199=$ sangat rendah

b. $0,20-0,399=$ rendah

c. $0,40-0,599=$ sedang 
d. $0,60-0,799=$ kuat

e. $0,80-1,000=$ sangat kuat

\section{Analisis Determinasi}

Secara umum koefisien determinasi untuk data silang (Crossection) relatif rendah karena adanya variasi yang besar antara masing-masing pengamatan, sedangkan untuk data runtut waktu (Time Series) biasanya mempunyai data koefisien determinasi yang lebih tinggi.

Dengan rumus sebagai berikut:

$\mathrm{Kd}=\mathrm{r}^{2} \mathrm{X} 100 \%$

\section{Pengujian Hipotesis}

\section{1) Uji T (Uji Parsial)}

Uji $\mathrm{T}$ pada dasarnya menunjukkan seberapa jauh pengaruh satu variabel penjelas/independen secara individual dalam menerangkan variasi variabel dependen (Ghozali, 2013: 98). Uji T atau disebut uji parsial digunakan untuk mengetahui pengaruh setiap variabel independen terhadap variable dependen. Berdasarkan signifikansi dasar, pengambilan keputusannya adalah jika signifikansi < 0,05, H1 diterima, sedangkan jika signifikansi > 0,05, H1 ditolak. Kriteria pengujian hipotesis Kriteria uji T menurut (Rusman,2011: 80) Apabila thitung $>\mathrm{t}$ tabel dengan $\mathrm{dk}=\mathrm{n}-2$ dan $\square 0.05$, maka H0 ditolak. Sebaliknya H1 diterima.

\section{2) Uji F (Uji Serempak)}

Uji F pada dasarnya menunjukkan apakah semua variabel independen atau bebas yang dimasukkan dalam model mempunyai pengaruh secara bersama-sama terhadap variabel dependen atau terikat (Ghozali, 2013: 98). Kegunaan uji F ini adalah untuk menguji apakah variabel gaya kepemimpinan (X1) dan kompensasi (X2) secara bersama-sama berpengaruh terhadap kinera aparatur Desa Sukamaju

Kriteria pengujiannya adalah sebagai berikut.

1. Taraf siginifikansi $(\alpha=0,05)$

2. Rumus df1 dan df 2 adalah: df $1=\mathrm{k}-1 ; \mathrm{df} 2=\mathrm{n}-\mathrm{k}$

3. Apabila $\mathrm{F}$ hitung $\geq \mathrm{F}$ tabel, $\mathrm{H} 0$ ditolak dan $\mathrm{H} 1$ diterima

4. Apabila F hitung $\leq \mathrm{F}$ tabel, $\mathrm{H} 0$ diterima dan $\mathrm{H} 1$ ditolak

Keterangan: $\mathrm{R}$ 2: Koefisien determinasi gabungan

$\mathrm{k}$ : Jumlah variabel

n: Jumlah sampel

\section{Hasil dan Pembahasan}

\subsection{Uji Validitas}

Hasil Uji Validitas Butir Kuesioner X1

\begin{tabular}{|c|c|c|c|c|c|c|}
\hline No & $\begin{array}{c}\text { Butir } \\
\text { Dalam } \\
\text { Kuesioner }\end{array}$ & $\begin{array}{c}\text { Koefisien } \\
\text { Korelasi } \\
(\mathrm{r})\end{array}$ & $\begin{array}{c}\text { Nilai } \\
\text { Kritis } \\
(\mathrm{r}- \\
\text { Tabel })\end{array}$ & $\begin{array}{c}\text { Sig.2 } \\
\text { tailed } \\
(\mathrm{p} \\
\text { level })\end{array}$ & $\begin{array}{c}\text { TarafSig. } \\
(\alpha=0,05)\end{array}$ & Keterangan \\
\hline 1 & $\mathrm{X} 1.1$ & $.252^{*}$ & 0.232 & 0.000 & 0,05 & Valid \\
\hline 2 & $\mathrm{X} 1.2$ & $.582^{* *}$ & 0.232 & 0.000 & 0,05 & Valid \\
\hline 3 & $\mathrm{X} 1.3$ & $.663^{* *}$ & 0.232 & 0.000 & 0,05 & Valid \\
\hline 4 & $\mathrm{X} 1.4$ & $.652^{* *}$ & 0.232 & 0.000 & 0,05 & Valid \\
\hline
\end{tabular}




\begin{tabular}{|c|c|c|c|c|c|c|}
5 & $\mathrm{X} 1.5$ & $.604^{* *}$ & 0.232 & 0.000 & 0,05 & Valid \\
\hline 6 & $\mathrm{X} 1.6$ & $.551^{* *}$ & 0.232 & 0.000 & 0,05 & Valid \\
\hline 7 & $\mathrm{X} 1.7$ & $.619^{* *}$ & 0.232 & 0.000 & 0,05 & Valid \\
\hline 8 & $\mathrm{X} 1.8$ & $.699^{* *}$ & 0.232 & 0.000 & 0,05 & Valid \\
\hline 9 & $\mathrm{X} 1.9$ & $.447^{* *}$ & 0.232 & 0.000 & 0,05 & Valid \\
\hline 10 & $\mathrm{X} 1.10$ & $.593^{* *}$ & 0.232 & 0.000 & 0,05 & Valid \\
\hline
\end{tabular}

Sumber : data primer (diolah), 2020

Hasil Uji Validitas Butir Kuesioner X2

\begin{tabular}{|c|c|c|c|c|c|c|}
\hline No & $\begin{array}{c}\text { Butir } \\
\text { Dalam } \\
\text { Kuesioner }\end{array}$ & $\begin{array}{c}\text { Koefisien } \\
\text { Korelasi } \\
(\mathrm{r})\end{array}$ & $\begin{array}{c}\text { Nilai } \\
\text { Kritis } \\
(\mathrm{r}- \\
\text { Tabel })\end{array}$ & $\begin{array}{c}\text { Sig.2 } \\
\text { tailed } \\
(\mathrm{p} \text { level })\end{array}$ & $\begin{array}{c}\text { TarafSig. } \\
(\alpha=0,05)\end{array}$ & Keterangan \\
\hline 1 & $\mathrm{X} 2.1$ & $.368^{* *}$ & 0.232 & 0.002 & 0,05 & Valid \\
\hline 2 & $\mathrm{X} 2.2$ & $.327^{* *}$ & 0.232 & 0.006 & 0,05 & Valid \\
\hline 3 & $\mathrm{X} 2.3$ & $.277^{*}$ & 0.232 & 0.020 & 0,05 & Valid \\
\hline 4 & $\mathrm{X} 2.4$ & $.601^{* *}$ & 0.232 & 0.000 & 0,05 & Valid \\
\hline 5 & $\mathrm{X} 2.5$ & $.611^{* *}$ & 0.232 & 0.000 & 0,05 & Valid \\
\hline 6 & $\mathrm{X} 2.6$ & $.489^{* *}$ & 0.232 & 0.000 & 0,05 & Valid \\
\hline 7 & $\mathrm{X} 2.7$ & $.471^{* *}$ & 0.232 & 0.000 & 0,05 & Valid \\
\hline 8 & $\mathrm{X} 2.8$ & $.444^{* *}$ & 0.232 & 0.000 & 0,05 & Valid \\
\hline 9 & $\mathrm{X} 2.9$ & $.407^{* *}$ & 0.232 & 0.000 & 0,05 & Valid \\
\hline 10 & $\mathrm{X} 2.10$ & $.305^{*}$ & 0.232 & 0.010 & 0,05 & Valid \\
\hline 11 & $\mathrm{X} 2.11$ & $.601^{* *}$ & 0.232 & 0.000 & 0,05 & Valid \\
\hline 12 & $\mathrm{X} 2.12$ & $.611^{* *}$ & 0.232 & 0.000 & 0,05 & Valid \\
\hline
\end{tabular}

Sumber : data primer (diolah), 2020

Hasil Uji Validitas Butir Kuesioner Y

\begin{tabular}{|c|c|c|c|c|c|c|}
\hline No & $\begin{array}{c}\text { Butir } \\
\text { Dalam } \\
\text { Kuesioner }\end{array}$ & $\begin{array}{c}\text { Koefisien } \\
\text { Korelasi } \\
(\mathrm{r})\end{array}$ & $\begin{array}{c}\text { Nilai } \\
\text { Kritis } \\
(\mathrm{r}- \\
\text { Tabel) }\end{array}$ & $\begin{array}{c}\text { Sig.2 } \\
\text { tailed } \\
(\mathrm{p} \text { level })\end{array}$ & $\begin{array}{c}\text { TarafSig. } \\
(\alpha=0,05)\end{array}$ & Keterangan \\
\hline 1 & Y.1 & $.546^{* *}$ & 0.232 & 0.000 & 0,05 & Valid \\
\hline 2 & Y.2 & $.346^{* *}$ & 0.232 & 0.000 & 0,05 & Valid \\
\hline 3 & Y.3 & $.599^{* *}$ & 0.232 & 0.000 & 0,05 & Valid \\
\hline 4 & Y.4 & $.595^{* *}$ & 0.232 & 0.000 & 0,05 & Valid \\
\hline 5 & Y.5 & $.544^{* *}$ & 0.232 & 0.000 & 0,05 & Valid \\
\hline 6 & Y.6 & $.423^{* *}$ & 0.232 & 0.000 & 0,05 & Valid \\
\hline 7 & Y.7 & $.346^{* *}$ & 0.232 & 0.000 & 0,05 & Valid \\
\hline 8 & Y.8 & $.650^{* *}$ & 0.232 & 0.000 & 0,05 & Valid \\
\hline 9 & Y.9 & $.433^{* *}$ & 0.232 & 0.000 & 0,05 & Valid \\
\hline 10 & Y.10 & $.531^{* *}$ & 0.232 & 0.000 & 0,05 & Valid \\
\hline
\end{tabular}

Sumber : data primer (diolah), 2020 


\subsection{Uji Reliabilitas}

Hasil Uji Reliabilitas Butir Kuesioner

\begin{tabular}{|c|c|c|c|}
\hline No & $\begin{array}{c}\text { Butir Dalam } \\
\text { Kuesioner }\end{array}$ & $\begin{array}{c}\text { Nilai } \\
\text { Alpha }\end{array}$ & Status \\
\hline 1 & Gaya Kepemimpinan (X1) & 0,758 & Reliabel \\
\hline 2 & Kompensasi (X2) & 0,666 & Reliabel \\
\hline 3 & Kinerja (Y) & 0,658 & Reliabel \\
\hline
\end{tabular}

Sumber : data primer (diolah), 2019

\subsection{Uji Normalitas}
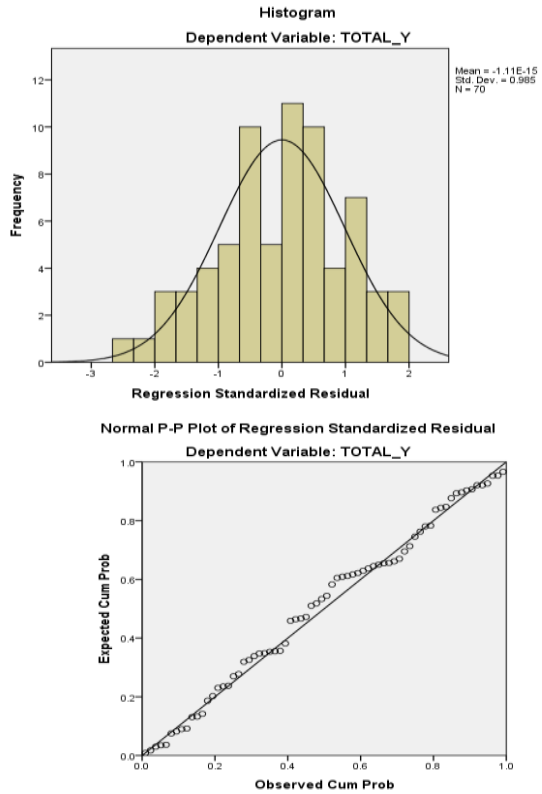

\subsection{Uji Multikolinieritas}

Hasil Uji Multikolinieritas

\begin{tabular}{|c|c|c|c|}
\hline \multicolumn{4}{|c|}{ Coefficients $^{\mathbf{a}}$} \\
\hline & & \multicolumn{2}{|c|}{ Collinearity Statistics } \\
\hline \multicolumn{2}{|c|}{ Model } & Tolerance & VIF \\
\hline \multirow[t]{3}{*}{1} & (Constant) & & \\
\hline & $\begin{array}{l}\text { Gaya } \\
\text { Kepemimpinan }\end{array}$ & 0,994 & 1,006 \\
\hline & Kompensasi & 0,994 & 1,006 \\
\hline
\end{tabular}

\subsection{Uji Heteroskedastisitas}


Hasil Uji Heteroskedastisitas

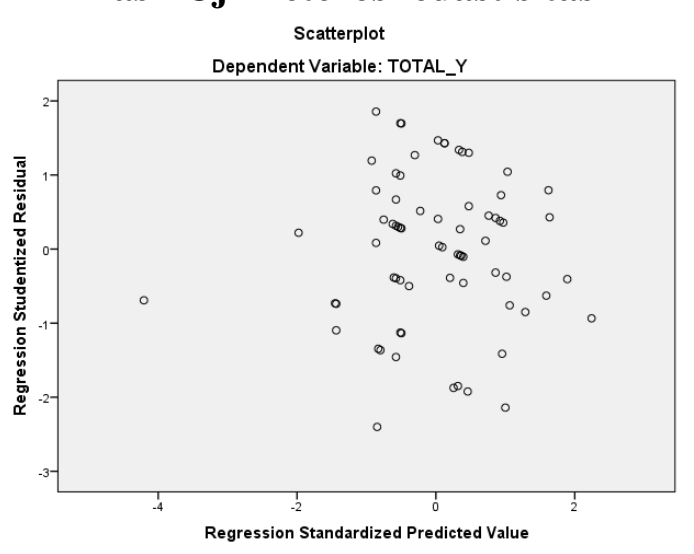

\subsection{Uji Regresi Linear Berganda}

Hasil Uji Regresi Linear Berganda

Coefficients $^{\mathrm{a}}$

\begin{tabular}{|c|c|c|c|c|c|c|}
\hline & & \multicolumn{2}{|c|}{$\begin{array}{l}\text { Unstandardized } \\
\text { Coefficients }\end{array}$} & \multirow{2}{*}{$\begin{array}{c}\text { Standardized } \\
\text { Coefficients } \\
\text { Beta }\end{array}$} & \multirow[b]{2}{*}{$\mathrm{t}$} & \multirow[b]{2}{*}{ Sig. } \\
\hline \multicolumn{2}{|c|}{ Model } & B & $\begin{array}{l}\text { Std. } \\
\text { Error }\end{array}$ & & & \\
\hline \multirow[t]{3}{*}{1} & (Constant) & 2,645 & 3,390 & & 0,780 & 0,438 \\
\hline & $\begin{array}{l}\text { Gaya } \\
\text { Kepemimpinan } \\
\text { (X1) }\end{array}$ & 0,855 & 0,034 & 0,950 & 25,099 & 0,000 \\
\hline & $\begin{array}{l}\text { Kompensasi } \\
\text { (X2) }\end{array}$ & 0,369 & 0,105 & 0,395 & 3,508 & 0,001 \\
\hline
\end{tabular}

a. Dependent Variable: Kinerja (Y)

Sumber : data primer (diolah), 2020

Berdasarkan tabel diatas dapat dibuat persamaan regresi linear sederhana sebagai berikut :

$Y^{\prime}=2,645+0,855 X 1+0,369 X 2$

Dari persamaan regresi di atas maka dapat diinterpretasikan beberapa hal, antara lain:

a. Nilai konstanta sebesar 2,645 yang berarti bahwa jika nilai variabel (X1) sebesar 0 dan nilai variabel (X2) sebesar 0 , maka variabel $\mathrm{Y}$ akan memiliki nilai sebesar 2,645.

b. Nilai koefisien regresi untuk variabel X1 adalah positif sebesar 0,855 dan hal ini menunjukkan bahwa Setiap kenaikan 1 satuan variabel X1 maka akan menaikkan nilai variabel $\mathrm{Y}$ sebesar 0,855 satuan dengan asumsi variabel lain bernilai tetap

c. Nilai koefisien regresi untuk variabel X2 adalah positif sebesar 0,369 dan hal ini menunjukkan bahwa Setiap kenaikan 1 satuan variabel X2 maka akan menaikkan nilai variabel $\mathrm{Y}$ sebesar 0,369 satuan dengan asumsi variabel lain bernilai tetap

\subsection{Analisis Korelasi}


Hasil Analisis Korelasi

Model Summary ${ }^{b}$

\begin{tabular}{|l|r|r|r|r|r|}
\hline Model & \multicolumn{1}{|c|}{$\mathrm{R}$} & R Square & $\begin{array}{c}\text { Adjusted R } \\
\text { Square }\end{array}$ & $\begin{array}{l}\text { Std. Error of } \\
\text { the Estimate }\end{array}$ & $\begin{array}{c}\text { Durbin- } \\
\text { Watson }\end{array}$ \\
\hline 1 & $.951^{\mathrm{a}}$ & .904 & .901 & 1.016 & 2.642 \\
\hline
\end{tabular}

a. Predictors: (Constant), TOTAL_X2, TOTAL_X1

b. Dependent Variable: TOTAL_Y

Sumber : Data diolah melalui SPSS 24, 2020

4.8. Uji Koefisien Determinasi $\left(\mathbf{R}^{2}\right)$

Rekapitulasi Analisis Determinasi

Model Summary ${ }^{b}$

\begin{tabular}{|l|r|r|r|r|r|}
\hline Model & $\mathrm{R}$ & R Square & $\begin{array}{c}\text { Adjusted R } \\
\text { Square }\end{array}$ & $\begin{array}{l}\text { Std. Error of } \\
\text { the Estimate }\end{array}$ & $\begin{array}{c}\text { Durbin- } \\
\text { Watson }\end{array}$ \\
\hline 1 & $.951^{\mathrm{a}}$ & .904 & .901 & 1.016 & 2.642 \\
\hline
\end{tabular}

a. Predictors: (Constant), TOTAL_X2, TOTAL_X1

b. Dependent Variable: TOTAL_Y

Sumber : Data diolah melalui SPSS 24, 2020

4.9. Hasil Uji t (Uji Parsial)

Hasil Uji t (Gaya Kepemimpinan X1 terhadap Kinerja Y)

Coefficients $^{\mathrm{a}}$

\begin{tabular}{|c|c|c|c|c|c|c|}
\hline & & \multicolumn{2}{|c|}{$\begin{array}{l}\text { Unstandardized } \\
\text { Coefficients }\end{array}$} & \multirow{2}{*}{$\begin{array}{c}\text { Standardized } \\
\text { Coefficients } \\
\text { Beta }\end{array}$} & \multirow[b]{2}{*}{$\mathrm{t}$} & \multirow[b]{2}{*}{ Sig. } \\
\hline \multicolumn{2}{|c|}{ Model } & $\mathrm{B}$ & $\begin{array}{l}\text { Std. } \\
\text { Error }\end{array}$ & & & \\
\hline \multirow[t]{2}{*}{1} & (Constant) & 2,645 & 3,390 & & 0,780 & 0,438 \\
\hline & $\begin{array}{l}\text { Gaya } \\
\text { Kepemimpinan } \\
\text { (X1) }\end{array}$ & 0,855 & 0,034 & 0,950 & 25,099 & 0,000 \\
\hline
\end{tabular}

a. Dependent Variable: Kinerja (Y)

Sumber : Data diolah melalui SPSS 24, 2020

Hasil Uji t (Kompensasi X2 terhadap Kinerja Y)

Coefficients $^{\mathbf{a}}$

\begin{tabular}{|c|c|c|c|c|c|c|}
\hline \multirow{2}{*}{\multicolumn{2}{|c|}{ Model }} & \multicolumn{2}{|c|}{$\begin{array}{l}\text { Unstandardized } \\
\text { Coefficients }\end{array}$} & \multirow{2}{*}{$\begin{array}{c}\text { Standardized } \\
\text { Coefficients } \\
\text { Beta }\end{array}$} & \multirow[b]{2}{*}{$\mathrm{t}$} & \multirow[b]{2}{*}{ Sig. } \\
\hline & & B & $\begin{array}{l}\text { Std. } \\
\text { Error }\end{array}$ & & & \\
\hline \multirow[t]{2}{*}{1} & (Constant) & 2,645 & 3,390 & & 0,780 & 0,438 \\
\hline & $\begin{array}{l}\text { Kompensasi } \\
\text { (X2) }\end{array}$ & 0,369 & 0,105 & 0,395 & 3,508 & 0,001 \\
\hline
\end{tabular}

a. Dependent Variable: Kinerja (Y)

Sumber : Data diolah melalui SPSS 24, 2020

\subsection{Hasil Uji F (Uji Serempak)}




\begin{tabular}{|c|c|c|c|c|c|c|}
\hline & & & $\begin{array}{l}\text { sil Uji } \\
\text { OVA }^{\mathbf{a}}\end{array}$ & & & \\
\hline & & $\begin{array}{l}\text { Sum of } \\
\text { Squares }\end{array}$ & df & Mean Square & $\mathrm{F}$ & Sig. \\
\hline 1 & Regression & 651.647 & 2 & 325.823 & 315.353 & $.000^{\mathrm{b}}$ \\
\hline & Residual & 69.224 & 67 & 1.033 & & \\
\hline & Total & 720.871 & 69 & & & \\
\hline
\end{tabular}

a. Dependent Variable: TOTAL_Y

b. Predictors: (Constant), TOTAL_X2, TOTAL_X1

Sumber : Data diolah melalui SPSS 24, 2020

\subsection{Pembahasan Hasil Penelitian}

Berdasarkan hasil pengolahan data diatas, penelitian ini menunjukkan bahwa variabel Gaya Kepemimpinan dan Kompensasi mempunyai pengaruh secara signifikan terhadap kinerja, dimana pada tabel 4.19 nilai $\mathrm{F}$ hitung sebesar 315.353 dan taraf signifikasi sebesar $0,000(\operatorname{sig} \alpha<0,05)$ hal ini sesuai dengan hipotesis yang diajukan.

Dari hasil pengujian parsial (Uji t) menggunakan program SPSS 24 diatas dapat dilihat pengaruh variabel gaya kepemimpinan dan variable kompensasi berpengaruh terhadap kinerja.

Berdasarkan hasil uji regresi antara gaya kepemimpinan terhadap kinerja terdapat hubungan yang Positif, hal ini mendefinisikan bahwa Ketika gaya kepemimpinan yang sesuai dengan Pegawai maka Kinerja Pegawai juga ikut meningkat (Hubungan Searah) artinya bahwa dalam taraf tertentu gaya kepemimpinan dapat meningkatkan Kinerja seorang Pegawai. Hasil analisis menunjukkan bahwa variabel kompensasi juga mempengaruhi Kinerja aparatur desa sukamaju kecamatan babat supat. Tanda koefisien regresi X2 yang menunjukkan hubungan yang searah, artinya jika variabel kompensasi meningkat ke arah yang lebih positif maka kemungkinan kinerja karyawan akan meningkat pula.

Kemudian hasil dari uji $\mathrm{F}$ dengan signifikansi sebesar 0.000 menunjukkan bahwa Gaya Kepemimpinan (X1) dan Kompensasi (X2) secara simultan berpengaruh positif dan signifikan terhadap Kinerja Pegawai (Y). Oleh karena itu, berdasarkan pemaparan di atas dapat disimpulkan bahwa variabel Gaya Kepemimpinan (X1) memiliki pengaruh positif terhadap Kinerja Pegawai (Y), maka hipotesis pertama dalam penelitian ini dapat diterima.

Selanjutnya variabel Kompensasi (X2) memiliki pengaruh yang signifikan terhadap kinerja pegawai. Sehingga hipotesis kedua pada penelitian iniyang menyatakan bahwa variable Kompensasi berpengaruh terhadap kinerja pegawai terbukti dan dapat diterima. 


\section{Kesimpulan} bahwa :

Berdasarkan dari permasalahan yang dibahas maka dapat disimpulkan

1. Berdasarkan hasil uji validitas keseluruhan butir kuesioner kuesioner gaya kepemimpinan (X1), Kompensasi (X2), dan kinerja (Y) dan bernilai valid, karena keseluruhan nilai butir kuesioner gaya kepemimpinan (X), Kompensasi (X2), dan kinerja (Y) lebih besar dari t tabel sebesar 0,232.

2. Berdasarkan hasil uji reliabilitas butir kuesioner butir kuesioner gaya kepemimpinan (X), Kompensasi (X2), dan kinerja (Y) diperoleh hasil bahwa butir kuesioner gaya kepemimpinan (X), Kompensasi (X2), dan kinerja (Y) bernilai reliabel karena nilainya lebih besar dari 0,6.

3. Berdasarkan perhitungan regresi diperoleh persamaan :

$Y^{\prime}=2,645+0,855 X 1+0,369 X 2$

Dengan keterangan:

a. Nilai konstanta sebesar 2,645 yang berarti bahwa jika nilai variabel (X1) sebesar 0 dan nilai variabel (X2) sebesar 0 , maka variabel $\mathrm{Y}$ akan memiliki nilai sebesar 2,645.

b. Nilai koefisien regresi untuk variabel X1 adalah positif sebesar 0,855 dan halini menunjukkan bahwa Setiap kenaikan 1 satuan variabel X1 maka akan menaikkan nilai variabel $Y$ sebesar 0,855 satuan dengan asumsi variabel lain bernilai tetap

c. Nilai koefisien regresi untuk variabel X2 adalah positif sebesar 0,369 dan hal ini menunjukkan bahwa Setiap kenaikan 1 satuan variabel X2 maka akan menaikkan nilai variabel $\mathrm{Y}$ sebesar 0,369 satuan dengan asumsi variabel lain bernilai tetap.

4. Berdasarkan perhitungan analisis korelasi besar pengaruh kuesioner gaya kepemimpinan (X) terhadap disiplin kerja (Y) adalah 0,951 yang berarti mempunyai hubungan yang sangat kuat karena berada pada kisaran 0,801,000 .

5. Berdasarkan hasil perhitungan analisis determinasi diketahui bahwa $R$ square $\left(\mathrm{R}^{2}\right)$ sebesar 0,901 atau sebesar 90\% gaya kepemimpinan dan kompensasi mempengaruhi kinerja Aparatur Desa sukamaju Kecamatan sungai Lilin sedangkan sebesar $10 \%$ dipengaruhi oleh variabel lain yang tidak dimasukkan kedalam penelitian ini

6. Hasil pengujian dengan SPSS untuk variabel Gaya Kepemimpinan (X1) terhadap Kinerja Karyawan (Y) diperoleh nilai t hitung $=25,099$ dengan tingkat signifikansi 0,000 . Maka didapat signifikansi $\alpha 0.05>$ Tingkat sifginifikansi 0.000 dan t hitung $>t$ tabel yaitu 25,099 > 1.667. Hal ini berarti H1 diterima yaitu Gaya Kepemimpinan (X1) berpengaruh secara parsial dan signifikan pada taraf $(\alpha)=5 \%$ terhadap Kinerja Pegawai (Y).

7. Hasil pengujian dengan SPSS untuk variabel Kompensasi (X2) terhadap Kinerja $(\mathrm{Y})$ diperoleh nilai $\mathrm{t}$ hitung $=3,508$ dengan tingkat signifikansi 0,000. Maka didapat signifikansi $\alpha 0.05>$ Tingkat sifginifikansi 0.000 dan $\mathrm{t}$ hitung $>\mathrm{t}$ tabel yaitu 3,508 > 1.667. Hal ini berarti $\mathrm{H} 1$ diterima yaitu Kompensasi (X2) berpengaruh secara parsial dan signifikan pada taraf $(\alpha)=5 \%$ terhadap Kinerja Pegawai (Y).

8. Pada kedua perhitungan yaitu $\mathrm{F}$ hitung $>\mathrm{F}$ tabel yaitu $315.353>3.13$ dapat disimpulkan bahwa $\mathrm{H} 2$ diterima bahwa variabel independen antara lain 


\section{DAFTAR PUSTAKA}

Arikunto, Suharsimi. 2012. Manajemen Penelitian. Jakarta: Rineka Cipta.

Badriyah, M. (2015). Manajemen Sumber Daya Manusia, Cetakan 1. Bandung: CV Pustaka Setia.

Colquitt, J., et al. (2011). Organizational behavior: Improving performance and commitment in the workplace. McGraw-Hill Irwin.

Eman, dkk. (2012), "Anilisis Penilaian Kinerja Pegawai Berbasis Kompetensi Di Satuan Polisi Pamong Praja Kabupaten Kerawang,” Jurnal Manajemen, Vol. 10, No. 1. http://eprints.ums.ac.id diakses tanggal 06 april 2020 pukul 22.15

Griffin, RickyW. 2014. Manajemen; edisi ketujuh jilid 2. Jakarta : Erlangga.

Ghozali, Imam. 2013. Aplikasi Analisis Multivariate dengan program SPSS. Edisi ke tujuh. Semarang: Badan penerbit universitas Diponegoro.

Handoko, 2014, Manajemen Personalia Sumber Daya Manusia, Edisi. Kedua,

Handoko, T. Hani. 2012, Manajemen, Cetakan Duapuluh, Yogyakarta : Penerbit BPEE.

Hasibuan, Malayu S.P. 2011. Manajemen: Dasar, Pengertian, dan Masalah. Edisi Revisi. Jakarta: Bumi Aksara

Hasibuan, Malayu S.P. 2014. Manajemen Sumber Daya Manusia. Edisi Revisi.Jakarta: Bumi Aksara.

Kartono, Kartini 2011. Pemimpin dan Kepemimpinan, Jakarta; Raja Grafindo Persada.

Mangkunegara, A. P. and A. Prabu (2015). Evaluasi kinerja sumber daya manusia. Bandung: Aditama.

Mangkunegara, A. P. (2016). Manajemen Sumber Daya Manusia Perusahaan. Bandung: PT Remaja Rosdakarya

Mink. 2013. Seri Manajemen Sumber Daya Manusia (Kinerja/Performance). Jakarta: PT Elik Media Koputindo.

Nitisimeto, A. S. (2015). Manajemen Personalia, cetakan kesembilan. Jakarta: Ghalia Indonesia.

Rivai, Veithzal. 2012, Manajemen Sumber Daya Untuk Perusahaan, Jakarta : PT. Raja Grafindo Persada.

Robbins, P. Stephen dan Mary Coulter. 2011. Manajemen, diterjemahkan oleh Bob Sabran, Wibi Hardani. Erlangga: Jakarta

Safroni, Lazdi, “Manajemen Pelayanan”, Aditya Media Publishing, Surabaya. 2012

Sedarmayanti. 2013. Manajemen Sumber Daya Manusia : Reformasi Birokrasi dan Manajemen Pegawai Negeri Sipil. Bandung. PT Refika Aditama.

Sentoso, Suryadi Perwiro. 2016. Model Manajemen Sumber Daya Manusia Indonesia, Asia dan Timur Jauh. Jakarta: Bumi Aksara.

Siagian, Sondang. 2012. Manajemen Sumber Daya Manusia. Jakarta: Bumi Aksara.

Simamora, Henry. 2013. Manajemen Sumber Daya Manusia. Edisi Ke-3. STIE YKPN. Yogyakarta

Sudarmanto, 2014.Kinerja dan Pengembangan Kompetensi SDM, Yogyakarta: Pustaka Pelajar.

Sugiyono.2012. Metodelogi Penelitian Bisnis. Edisi Kelima. Bandung: CV. Alfabeta.

Sugiyono. 2013. Metode Penelitan Pendidikan: Pendekatan Kuantitatif, Kualitatif,dan R\&D. Bandung: Alfabeta.

Sugiyono, 2013. Memahami Penelitian Kualitatif. Bandung: ALFABETA.

Sugiyono. (2013). Statistik untuk Penelitian. Bandung: CV. Alfabeta

Sumarsono, Sonny. 2009. Ekonomi Sumber Daya Manusia. Yogyakarta: STIE YKPN.

Suwanto \& Priansa, D. 2011. Manajemen SDM dalam Organisasi Publik dan Bisnis. Bandung: Alfabeta. 
Thoha, Miftah. 2009. Kepemimpinan dalam Manajemen, Ed.1, Cet.2. Jakarta: bumi aksara Thoha, Miftah. (2011). Perilaku Organisasi. Jakarta: Raja Grapindo Persada.

Wibowo, 2016. Manajemen Kinerja, Edisi Ketiga.Jakarta : Rajawali Pers..

Widodo, Parwoto. 2016. Pengaruh Gaji Pada Hubungan Antara Kompensasi Dan Kepemimpinan Terhadap Kepuasan Kerja Studi Pada Kantor Pelayanan Pajak Salatiga. http://eprints.ums.ac.id diakses pada tanggal 06 april 2020 pukul 22.20

Yulk, G., 2009, Kepemimpinan Dalam Organisasi, Jakarta, PT Indeks.

Ismi Herdyanti 2017, Hubungan Kompensasi Terhadap Kinerja Karyawan. https://herdyantismi.wordpress.com/2013/11/20/ diakses pada tanggal 07 april 2020 pukul: 23.47

https://artikelkuliahkita.blogspot.com/2017/04/hubungan-antara-gaya-kepemimpinan.html diakses pada tanggal 07 april 2020 pukul: 23.51 